Katarzyna Anna Blacharska-Krzanowska, ${ }^{10}$, Kartarzyna Anna Strzępek ${ }^{1,2}$, Jarosław Woron' ${ }^{3}$, Teresa Weber-Lipiec ${ }^{2}$

${ }^{1}$ Clinic of Pain Treatment and Palliative Care, Chair of Internal Medicine and Gerontology,

Collegium Medicum Jagiellonian University, Kraków

${ }^{2}$ Department of Palliative Medicine, Clinic of Internal Medicine and Geriatrics, University Hospital, Kraków

${ }^{3}$ Department of Clinical Pharmacology, Chair of Pharmacology, Collegium Medicum Jagiellonain University, Kraków

\title{
How to manage exacerbation of respiratory failure in a patient diagnosed with amyotrophic lateral sclerosis
}

\begin{abstract}
Amyotrophic lateral sclerosis (ALS) is a debilitating neurodegenerative disease of unclear pathogenesis, which leads to the damage of motor neurons. The majority of patients survive two to five years after a diagnosis is made. Despite numerous clinical trials and some progress in understanding ALS pathology, no treatment that effectively inhibits the disease progression has been developed. The aim of this paper is to review a patient's disease history from diagnosis, through the occurrence of respiratory failure features, until the start of non-invasive ventilation (NIV), including the assessment of the efficacy of this therapy during respiratory failure exacerbation. ALS is an incurable disease, but many of its symptoms may be relieved, and therapy should be aimed at quality of life improvement and maintaining the patient's independence and comfort as long as possible. Better quality of life and longer survival are currently well-established advantages of NIV.
\end{abstract}

Palliat Med Pract 2020; 14, 1: 44-50

Key words: amyotrophic lateral sclerosis, respiratory failure, non-invasive ventilation, chronic obstructive pulmonary disease

\section{Introduction}

Amyotrophic lateral sclerosis (ALS) is a debilitating neurodegenerative disease of relatively unknown aetiology. In the majority of cases ALS occurs in a sporadic manner, without any risk factors determined, while familial forms comprise $5-10 \%$ of cases; they are inherited mostly by autosomal-dominant mechanism and, to a lesser extent, by autosomal recessive and chromosome X-linked mechanisms [1]. Mutation of copper-zinc superoxide dismutase (SOD1) is found in 20-30\% cases of autosomal-dominant familial disease. Until recently, a combination of environmental and genetic factors was considered to have a significant effect on the risk of sporadic ALS; however, currently it is known that it is not the sole and most common mutation $(20 \%)$, because other mutations, such as in genes C9ORF72 (34\%), TARDBP (6.5\%), FUS (3-5\%), as well as sporadic ones, have been identified. Other research revealed several factors influencing the dura-

\footnotetext{
Address for correspondence:

Katarzyna Anna Blacharska-Krzanowska

Clinic of Pain Treatment and Palliative Care, Chair of Internal Medicine and Gerontology,

Collegium Medicum Jagiellonian University, Kraków

e-mail: kkrzanowska@op.pl
}

Palliative Medicine in Practice 2020; 14, 1, 44-50

Copyright (C) Via Medica, ISSN 2545-0425

DOI: 10.5603/PMPI.2020.0006 
tion of the disease and the age of onset of first symptoms; earlier diagnosis was noted in Asian populations and male subjects $[2,3]$. On the other hand, shorter survival from diagnosis is associated with later onset of first symptoms of ALS [4].

Studies conducted by Mitchell et al. on a group of 1288 patients undergoing comprehensive assessment of incidence of conditions preceding ALS diagnosis revealed that disease entities such as arthritis, non-ALS neurological disease, liver diseases, chronic obstructive pulmonary disease (COPD), kidney diseases, asthma, diabetes, hypertension, obesity, and hyperlipidaemia were statistically less common in the ALS patient group as compared with the control group matched for age, gender, and place of residence [5]. Authors of a larger study confirmed the presence of ALS-preceding disease, larger onset of motor neuron disease in patients with preceding diseases, and negative correlation between the age of diagnosis and duration of the disease [6]. The above-mentioned results were confirmed in several smaller studies, which may strongly support possible hypotheses of neuroprotection $[7,8]$.

ALS diagnosis is based on the clinical picture, neurological examination, electrophysiological examinations, and differential diagnosis. In 1994 the Research Group for Motor Neuron Diseases at the World Federation of Neurology developed and published diagnostic criteria, which, after modification in 1998 (EI Escorial World Federation of Neurology) and review of an expert team in 2006, resulted in the development of the so-called Awaji algorithm (Consensus Conference of International Federation of Clinical Neurophysiology, IFCN) [9]. According to current criteria, there are three clinical forms of ALS: clinically definite ALS, clinically probable ALS, and clinically probable-laboratory supported ALS. Its assumed that approximately $10 \%$ of patients with initial suspicion of ALS suffer from some other condition; therefore, motor neuron disease should be differentiated from other disease with clinical symptoms overlapping or similar to those occurring in ALS, such as cervical radiculomyelopathy, myasthenia gravis, multifocal motor neuropathy (MMN-CB), spinal muscular atrophy (SMA), multiple sclerosis (MS), and Kennedy's disease (SBMA) [8]. For this reason, additional investigations are recommended, such as magnetic resonance imaging (MRI) of the brain and spinal cord, tests of cerebrospinal fluid (CSF), and certain serology tests. Electrophysiological examinations performed during workup are used also to rule out other disease processes. A clinical feature specific to ALS is a combination of symptoms associated with damage to upper motor neurons (UMN) and lower motor neurons (LMN) of progressive course [10]; however, it should be mentioned that intensity of symptoms of damage of lower and upper motor neurons may not be identical and that not all specific symptoms must be present.

Damage and gradual atrophy of motor neurons in spinal cord anterior horns, motor neurons in cerebral cortex, and cranial nerve nuclei result in the development of a specific clinical picture. Increasing spasticity, exaggerated muscle reflexes, and abnormal reflexes are symptoms of upper motor neuron damage, while the presence of flaccid paresis, skeletal muscle atrophy, fasciculations, and diminishing or absence of muscle reflexes indicate progressing damage to the anterior horn of the spinal cord and cranial nerve nuclei.

Onset of the disease is usually indicated by symptoms within upper extremities - weakening of the muscles of the hands and forearms, but they may also start from the shoulder girdle, and within the lower extremities - usually from weakening of foot dorsiflexion (foot drop). This is classical form of the disease, providing over $2 / 3$ of cases. In some patients spastic paraparesis of lower extremities is the initial symptom.

Bulbar-onset ALS, which affects approximately $20 \%$ of ALS patients, features the occurrence of speech and swallowing disorders (developing dysarthria). Gradually progressing dyspnoea, initially during exercise and finally at rest, results from the damage of lower motor neurons. Impaired diaphragm performance may cause orthopnoea and respiratory disturbances during sleep. Respiratory disorders usually appear at the late stage of the disease, but there are ALS cases described in which symptoms of respiratory failure manifest at the early stage of the disease [12] and commonly cause aspiration and then aspiration pneumonia, which may be a direct cause of the patient's death.

The relationship between ALS and cognitive dysfunction and frontotemporal dementia (FTD) has been shown in several studies. FTD has been found in up to $15 \%$ of people with ALS, and a further $35 \%$ may show evidence of frontal lobe dysfunction, with behavioural or cognitive changes. There is a spectrum from pure FTD to pure ALS with a spread between these extreme, particularly for people with the C9orf72 gene, and the symptoms of ALS may follow the diagnosis of FTD [13-16]. Cognitive function impairment involves problems with executive function, language use, relative memory saving, and visuospatial function. Typical behavioural changes noted in the course of the disease include apathy, indifference, disinhibition, inadequate behaviours, or disturbances in nutritional habits. No superficial or deep sensation disorders are noted; however, nociceptive pain may occur, resulting from various causes, such as decreased mobility, muscle 
cramps, spasticity and other concomitant disease, e.g. neuropathic disorders in the course of diabetes.

ALS is a constantly progressing disorder of almost always linear clinical course, which inevitably leads to death, while the rate of progression features interindividual variability, without periods of remission or exacerbation, but also without periods of symptom stability. Almost $25 \%$ of patients die within two years of diagnosis, and half of patients survive 3-4 years; however, also survival for more than 10 years can occur. Approximately $5 \%$ of patients survive longer than 10 years [17]. The mean duration of the disease is four years.

The aim of this paper was to review a case history involving a patient diagnosed with ALS, with special focus on the clinical issues surrounding the use of non-invasive ventilation during exacerbations of respiratory failure.

\section{Case report}

A 77-year-old male with motor neuron disease (ALS) presented himself to the Palliative Medicine Department for qualification to and implementation of non-invasive ventilation (NIV). Detailed neurological history revealed weakening of muscular strength of lower extremities gradually worsening for the last eight years and distal weakening of the upper extremities for several months, resulting in paresis of the lower extremities, drowsiness during the daytime, morning fatigue and gradually increasing dyspnoea for a month, particularly during exercise, and dyspnoea attacks during the night-time, worsening weakness, referred to by the patient as "losing strength", problems with articulation of words, and loss of appetite with significant weight loss and indigestion. Moreover, the patient noted repeating accumulation of mucous discharge in his airways in the morning forcing him to cough it out, increased salivation, in particular during the night, and increased unproductive cough during daytime, which he associated with his COPD until now.

His history revealed that progressively reducing strength of lower extremities was the reason for constant workup and neurological check-ups and several hospital stays; during his last stay in 2017 suspicion of motor neuron disease was raised and sensorimotor polyneuropathy was diagnosed. Due to results of electromyography, involving the presence of neuropathic changes that did not fulfil the neurophysiological part of the El Escorial criteria, the patient was referred to the Neurology Clinic, where motor neuron disease was confirmed on the basis of worsening symptoms of muscular strength weakening and respiratory failure reported by the patient, as well as additional exami- nations. The patient, with numerous comorbidities, including COPD with exacerbations occurring from time to time requiring temporary intensification of therapy (multiple occurrences of decreased FEV 1 values were noted in the provided pulmonary function test results), bronchiectasis, ischaemic heart disease, history of myocardial infarctions: in 2008 treated with coronary angioplasty involving implantation of a BMS into the RCA and in 2012 treated with $\mathrm{PCl}$ involving implantation of a BMS into the LCX and a DES into the LAD, cardiac arrhythmia in the form of paroxysmal atrial fibrillation, chronic heart failure, arterial hypertension, narrow spinal canal syndrome, history of lumbar spine stabilisation surgery in 2013, and degenerative- and discopathy-related lesions within the lumbar spine. Due to numerous exacerbations of progressive respiratory failure the patient had been under observation several times in an ER and hospitalised in departments of internal medicine or pulmonology.

In January 2019, due to neuromuscular disease concomitant with COPD, the patient was referred to the Pulmonology Department for verification of indications to NIV. An examination of arterial blood gases performed during his stay revealed transient hypoxaemia, without hypercapnia or acidosis; respiratory system function tests revealed features of severe irreversible obstruction with $\mathrm{FEV}_{1} 42 \%$; body plethysmography did not reveal features of restrictive disease, and diffusion lung capacity for carbon monoxide (DLCO) was $62 \%$ of the predicted value (results stable as compared to the previous ones). Moreover, polysomnography was performed, which did not reveal sleep respiratory disorders. During one of his stays in the Pulmonology Department lower respiratory tract infection developed; after therapeutic failures and bacteriology tests of sputum culture where Haemophilus influenzae and Moraxella catarrhalis were grown, targeted antibiotic therapy was started resulting in the improvement of his general status. Simultaneously, bronchoscopy, involving aspiration of discharge from bronchial tree, was performed; the presence of pathogens in biological material was confirmed, and therapy was supplemented with respiratory rehabilitation with postural bronchial drainage.

At admission the patient was in moderately good general status, verbally responsive, of normosthenic constitution; physical examination: auscultation revealed decreased vesicular murmur over lung fields with small basal and single crackles, regular heart action approximately $90 \mathrm{bpm}$, dough-like oedema of left lower extremity up to 1/2 of lower leg, abdomen soft to palpation, without abnormal mass, skin dry, pale, mottled skin of lower extremities, pulse palpable on popliteal and femoral arteries, non-palpable on 
dorsalis pedis arteries, joint outlines unremarkable, decreased strength and tone of lower extremity muscles, unremarkable range of passive motion in joints of extremities, and absence of active motion in ankle joints. Neurological examination at admission revealed positive frontal release signs (snout and palmomental reflexes), single fasciculations within extremities, small distal paresis of upper extremities and significant paresis of lower extremities, more prominent distally and on the left side, muscular atrophy involving mostly small hand muscles, regular deep tendon reflexes in upper extremities, Jacobsohn sign positive bilaterally, in lower extremities: weak knee reflexes, loss of ankle jerk and plantar reflexes, no superficial sensation disorders, steppage gait with significant impairment of toe stand and to a lesser extent heel stand, the patient walks with two elbow crutches.

During the stay the patient's status deteriorated, problems occurred with coughing out and change of nature of airway discharge, auscultation revealed features of increased obstruction, prolongation of expiratory phase, and saturation without oxygen therapy was $88 \%$. In physical examination retraction of intercostal spaces and increasing lower extremity oedemas were noted. Increasing features of respiratory failure resulted in rapid diagnostic intervention. Laboratory tests revealed elevated levels of C-reactive protein $120 \mathrm{mg} / \mathrm{L}$, procalcitonin $1.13 \mathrm{ng} / \mathrm{mL}$ and leukocytes $15.11 \quad 103 / \mu \mathrm{L}$, neutrophils $83.4 \%$; other investigations: chest X-ray revealed peribronchial inflammatory infiltrations bilaterally, while blood gas analysis revealed hypercapnia $\left(\mathrm{pO}_{2} 71.4 \mathrm{~mm} \mathrm{Hg}\right.$, $\mathrm{pCO}_{2} 49.5 \mathrm{~mm} \mathrm{Hg}$ ); abdominal ultrasound scan did not reveal significant abnormalities apart from right kidney cysts. Results of X-ray, considered together with signs and symptoms and laboratory results justified the diagnosis of respiratory failure secondary to bronchial pneumonia and exacerbation of chronic obstructive lung disease.

Other laboratory results were necessary for the evaluation of the function of organs such as kidneys and liver, to adjust further treatment to organ performance. Due to the lack of bacteriological tests, empirical antibiotic therapy was applied in the treatment, i.e. cefotaxime and levofloxacin at individually tailored dosages, in line with guidelines on the management of hospital-acquired pneumonia, taking into consideration local phenotypes of susceptibility of isolated organisms (Infectious Diseases Society of America and American Thoracic Society, 2016); however, the antibiotic therapy was chosen on the basis of a bacterial test of lower respiratory tract discharge collected during bronchoscopy in January 2019. Moreover, corticosteroid therapy and nebulisa- tions with a bronchodilator, steroid, and mucokinetic drug were applied.

Due to the presence of respiratory failure features, the decision was made to start NIV earlier, initially in a two-hours three times daily regimen with oxygen therapy. In line with current guidelines on starting NIV in the course of ALS, also guidelines on management of COPD exacerbations in line with GOLD 2019 were followed. Due to decreasing albumin level, the patient's diet was supplemented with high-protein formulas. A consulting angiology surgeon determined that lower limb paresis was the primary reason for their oedema and ordered compression therapy. A comprehensive approach to the patient, pharmacological therapy, NIV, adjunctive treatment (diet, compression therapy, and respiratory rehabilitation) enabled improvement in general status, remission of inflammatory infiltrations in X-ray, and resolution of auscultation findings. The improvement was demonstrated in subsequent results of blood gas test performed in the first day of stay and then, after placement of arterial line, on a regular basis from the moment of diagnosis of pneumonia accompanied with respiratory failure exacerbation, to monitor disturbances of acid-base balance and gas exchange (Table 1). Further management involved continuation of nebulisations with steroid, $\beta_{2}$-mimetic and ipratropium bromide, erdosteine for a certain time, methylprednisolone with recommendation of gradual dose decrease, recommendation of continuation of aspirin, riluzole $100 \mathrm{mg}$, ramipril, $\beta$-adrenolytic agent, anti-oedema therapy with potassium supplementation, and LMWH at prophylactic dose. The patient was discharged in optimal clinical status under the care of his family, as well as a Home Ventilation Team and Palliative Medicine Clinic.

\section{Discussion}

Progressive neuromuscular impairment is the most common cause of death in ALS. Involvement of the respiratory system is an almost constant feature of ALS with usually rapid progression leading to respiratory failure that may manifest as dyspnoea, but also as shallow cough, sleep disturbances with frequent awakenings and/or excessive drowsiness during daytime, fatigue, morning headache, or even delirium. This fact substantiates systematic, careful clinical assessment that is necessary for early detection of respiratory symptoms associated with respiratory muscle insufficiency. Nocturnal respiratory disorders, in the form of obstructive sleep apnoea or hypoventilation, are indirectly suggested by symptoms reported by the patients, such as daytime drowsiness, fatigue, or morning headache. Check-up of the patient's status 
Table 1. The results of laboratory tests

\begin{tabular}{lllllll} 
Day of stay & $\mathrm{pH}$ & $\mathrm{pCO}_{2} \mathrm{~mm} \mathrm{Hg}$ & $\mathrm{pO}_{2} \mathrm{~mm} \mathrm{Hg}$ & $\mathrm{Sat} . \mathrm{O}_{2} \%$ & $\mathrm{HCO}_{3} \mathrm{mmol} / \mathrm{L}$ & $\mathrm{BE} \mathrm{mmol} / \mathrm{L}$ \\
\hline Day 1 & 7.389 & 37.3 & 93.4 & 94 & 22.7 & -2.2 \\
\hline Day 14 & 7.274 & 49.5 & 71.4 & 88 & 22.4 & -1.6 \\
\hline Day 15 & 7.298 & 50.2 & 59.6 & 87 & 23.7 & -2.5 \\
\hline $\begin{array}{l}\text { Day 16 } \\
8.00 \text { AM }\end{array}$ & 7.398 & 49.9 & 84.2 & 89 & 24.3 & -0.8 \\
\hline $\begin{array}{l}\text { Day 16 } \\
12.30 \text { PM }\end{array}$ & 7.424 & 37.3 & 87.4 & 93 & 24.6 & 0.1 \\
\hline $\begin{array}{l}\text { Day 17 } \\
8.00 \text { AM }\end{array}$ & 7.396 & 42 & 80.3 & 92 & 25 & 0.9 \\
\hline $\begin{array}{l}\text { Day 17 } \\
12.30 \text { PM }\end{array}$ & 7.409 & 89.8 & 39.5 & 93 & 24.8 & 0.4 \\
\hline $\begin{array}{l}\text { Day 18 } \\
8.00 \text { AM }\end{array}$ & 7.18 & 106 & 40 & 96 & 25.6 & 1.3 \\
\hline $\begin{array}{l}\text { Day 18 } \\
12.30 \text { PM }\end{array}$ & 7.422 & 78.4 & 38.9 & 90 & 25.3 & 1.0 \\
\hline
\end{tabular}

Table 2. Indications for non-invasive ventilation in patients with chronic obstructive pulmonary disease exacerbation

\begin{tabular}{l} 
Indications for NIV in patients with COPD exacer- \\
bation \\
$\begin{array}{l}\text { Respiratory acidosis }\left(\mathrm{PaCO}_{2}>6.0 \mathrm{kPa} \text { or } 45 \mathrm{~mm} \mathrm{Hg}\right. \\
\text { and arterial blood } \mathrm{pH}<7.35)\end{array}$ \\
\hline $\begin{array}{l}\text { Intense dyspnoea with symptoms suggestive of } \\
\text { fatigue of respiratory muscles and/or increased res- } \\
\text { piratory effort (use of accessory respiratory muscles, } \\
\text { paradoxical diaphragm movements, retraction of } \\
\text { intercostal spaces) }\end{array}$ \\
\hline Persistent hypoxaemia despite oxygen therapy \\
\hline
\end{tabular}

should include physical examination with the assessment of progressive muscle weakening and additional investigations to assess progressive decrease of lung vital capacity (spirometry). The primary limitation of spirometry involves difficulties in performing the examination in the presence of progressive neuromuscular insufficiency in ALS. Suspected obstructive sleep apnoea should be confirmed by means of conventional polysomnography.

Despite progress in medicine, the management of ALS still involves mostly supportive therapies and is focused on respiratory system prophylaxis, including improved ventilation and removal of discharge accumulated in the respiratory tract. The use of riluzole is recommended in the management because it is the only medication with demonstrated efficacy, prolonging median survival of ALS patients by $2-3$ months. Miller et al. showed that riluzole given at dose $100 \mathrm{mg}$ daily increased yearly survival by as much as
$15 \%$ and prolonged survival by almost three months after an 18-month treatment course [18], while no effect on subjective patients' impression was noted, in particular at advanced stage of the disease. In subsequent research, significant prolongation of survival was noted, by 7-12 months on average, in patients treated with NIV $[19,20]$.

NIV is one method of management of chronic respiratory failure, and in this indication it substitutes the lost function of respiratory system and, as the disease progresses, it is supposed to improve the quality of life. Current criteria of starting NIV in ALS patients with acute hypercapnic respiratory failure, e.g. secondary to respiratory tract infection, involve tachypnoea $>20$ breaths/minute with vital capacity $<1$ litre or respiratory acidosis with $\mathrm{pH}<7.35$ and $\mathrm{pCO}_{2}>50 \mathrm{~mm} \mathrm{Hg}$, and in patients with concomitant COPD and acute respiratory failure - presence of respiratory acidosis with $\mathrm{pH}<7.35$ and $\mathrm{pCO}_{2}>45 \mathrm{~mm}$ $\mathrm{Hg}$, and respiratory rate $>23 / \mathrm{min}$, with the lack of response to bronchodilator therapy [21] (Table 2).

The presence of comorbidities leading to exacerbation of respiratory failure provides a significant clinical challenge. COPD risk factors are also risk factors of frequency and severity of exacerbations and, as such, provide potential targets of rapid pharmacological and supportive interventions. They include quitting smoking, prevention of respiratory system infection, and avoiding rapid decrease of lung function. A decrease of $\mathrm{FEV}_{1}$ value is particularly associated with worsened symptoms and increased inflammatory response. The mode and intensity of ventilation may vary significantly in individual patients, depending on particular indications to NIV. Current criteria for starting NIV 
therapy in ALS patients are clear; however, there are premises that could justify earlier implementation of NIV. In several studies evidence of the decreased rate of lung function loss was found [22]; however, there are reports indicating that, despite confirmation of the decreased loss of lung function, such a slowdown was not unequivocally associated with the time of NIV start [19]. There are still advantages of earlier implementation of NIV, not associated with modification of the disease progression. For example, early implementation should be taken into consideration in patients with poor compliance, in particular in those with bulbar symptoms.

NIV is not recommended for constant, long-term use due to the risk of local skin damage at the site of contact with the mask, even including pressure sores, in particular in patients with decreasing albumin level due to cachexia. Other limitations of the therapy, with high risk of complications of the ventilation or its failure to provide the expected outcome, include: severe bulbar impairment, respiratory tract obstruction, thick discharge accumulated in respiratory tract, inability to maintain a position appropriate for use of the mask or mask intolerance, poor compliance resulting from e.g. dementia or weakness, and impaired cough reflex.

Management of accumulating discharge that hinders the use of NIV provides a particular challenge in ALS patients with bulbar symptoms, for whom invasive ventilation (IV) with the use of a tracheostomy tube remains the method of choice in terms of efficacy. IV, as an invasive method, significantly worsens the quality of life, when compared with NIV. Researchers suggest that focusing on the control of respiratory discharge accumulation is of particular importance for complying with NIV recommendations, and implementation of appropriate techniques of its removal, concomitant pharmacotherapy, and rehabilitation and then offering NIV at the early stage of ALS, has a significant effect on increasing tolerance of NIV, allowing it to be used in patients with bulbar-onset ALS.

The still growing body of scientific reports suggests that among patients with neuromuscular disease, and ALS in particular, who receive short-term constant invasive ventilation in the case of complication in the form of acute respiratory failure, NIV may reduce the need for invasive ventilation, shorten the duration of ICU stay, and improve the mortality rate [19]. In patients with accompanying respiratory tract obstruction requiring nebulisation, it should be applied during intervals in NIV. When needed, in NIV-dependent patients, during exacerbation periods medications may be administered by means of a nebuliser connected to the ventilator. Research has shown that, in stable patients, bronchodilators provide more benefits when administered during intervals in NIV, which may also facilitate cough and effective coughing out.

\section{Conclusions}

Better quality of life and longer survival are currently well-established advantages of NIV, irrespective of whether implementation of NIV is associated with the criteria in force (hypercapnia) or used before an expected decrease of lung vital capacity. Although optimal time of NIV therapy implementation is an important factor, nothing is more important than confidence that all patients qualifying to assisted ventilation will receive it, together with support from experienced ventilation teams. Undoubtedly, the inability to take advantage of care from home hospice teams and therapy-supporting visits to a Palliative Medicine Clinic within the same period provides a problem, particularly because palliative care teams may help in making decisions concerning the aims and preferences of patients, and may provide constant care focused on relief of symptoms. Consideration of qualification to NIV, as well as potential benefits and risk of complications, is always the responsibility of the doctor, who is obliged to explain all its limitations to the patient.

\section{Conflict of interests}

Authors declare no conflict of interest.

\section{Funding}

This study has no funding.

No identifiable information about the patient are included in the paper.

\section{References}

1. Shaw PJ. Molecular and cellular pathways of neurodegeneration in motor neurone disease. J Neurol Neurosurg Psychiatry. 2005; 76(8): 1046-1057, doi: 10.1136/jnnp.2004.048652, indexed in Pubmed: 16024877.

2. Liu ZJ, Lin HX, Wei Q, et al. Genetic Spectrum and Variability in Chinese Patients with Amyotrophic Lateral Sclerosis. Aging Dis. 2019; 10(6): 1199-1206, doi: 10.14336/AD.2019.0215, indexed in Pubmed: 31788332.

3. Wei Q, Chen X, Zheng Z, et al. The predictors of survival in Chinese amyotrophic lateral sclerosis patients. Amyotroph Lateral Scler Frontotemporal Degener. 2015; 16(3-4): 237 244, doi: 10.3109/21678421.2014.993650, indexed in Pubmed: 25581512.

4. Coan G, Mitchell CS. An Assessment of Possible Neuropathology and Clinical Relationships in 46 Sporadic Amyotrophic Lateral Sclerosis Patient Autopsies. Neurodegener Dis. 2015; 15(5): 301-312, doi: 10.1159/000433581, indexed in Pubmed: 26183171.

5. Hollinger SK, Okosun IS, Mitchell CS, et al. Antecedent Disease is Less Prevalent in Amyotrophic Lateral Sclerosis. Neurodegener Dis. 2015; 15(2): 109-113, doi: 10.1159/000369812, indexed in Pubmed: 25720304. 
6. Hollinger SK, Okosun IS, Mitchell CS. Antecedent Disease and Amyotrophic Lateral Sclerosis: What Is Protecting Whom? Front Neurol. 2016; 7: 47, doi: 10.3389/fneur.2016.00047, indexed in Pubmed: 27065942.

7. de Carvalho M, Dengler R, Eisen A, et al. Electrodiagnostic criteria for diagnosis of ALS. Clin Neurophysiol. 2008; 119(3): 497-503, doi: 10.1016/j.clinph.2007.09.143, indexed in Pubmed: 18164242.

8. Zoccolella S, Beghi E, Palagano G, et al. Analysis of survival and prognostic factors in amyotrophic lateral sclerosis: a population based study. Journal of Neurology, Neurosurgery \& Psychiatry. 2008; 79(1): 33-37, doi: 10.1136/jnnp.2007.118018.

9. Geevasinga N, Howells J, Menon P, et al. Amyotrophic lateral sclerosis diagnostic index: Toward a personalized diagnosis of ALS. Neurology. 2019; 92(6): e536-e547, doi: 10.1212/WNL.0000000000006876, indexed in Pubmed: 30709964.

10. Iłżecka J, Iłżecka J. Mechanizmy patogenetyczne stwardnienia bocznego zanikowego. Aktualn Neurol. 2012; 12: 222-235.

11. Wijesekera LC, Leigh PN, Wijesekera LC, et al. Amyotrophic lateral sclerosis. Orphanet J Rare Dis. 2009; 4: 3, doi: 10.1186/1750-1172-4-3, indexed in Pubmed: 19192301.

12. Brooks BR, Miller RG, Swash M, et al. World Federation of Neurology Research Group on Motor Neuron Diseases, World Federation of Neurology Research Group on Motor Neuron Diseases. El Escorial revisited: revised criteria for the diagnosis of amyotrophic lateral sclerosis. Amyotroph Lateral Scler Other Motor Neuron Disord. 2000; 1(5): 293-299, doi: 10.1080/146608200300079536, indexed in Pubmed: 11464847.

13. Beeldman E, Raaphorst J, Klein Twennaar M, et al. The cognitive profile of ALS: a systematic review and meta-analysis update. J Neurol Neurosurg Psychiatry. 2016; 87(6): 611-619, doi: 10.1136/jnnp-2015-310734, indexed in Pubmed: 26283685.

14. Crockford C, Newton J, Lonergan K, et al. ALS-specific cognitive and behavior changes associated with advancing disease stage in ALS. Neurology. 2018; 91(15): e1370-e1380, doi: 10.1212/WNL.0000000000006317, indexed in Pubmed: 30209236.
15. Woolley SC, Strong MJ, Woolley SC, et al. Frontotemporal Dysfunction and Dementia in Amyotrophic Lateral Sclerosis. Neurol Clin. 2015; 33(4): 787-805, doi: 10.1016/j. ncl.2015.07.011, indexed in Pubmed: 26515622.

16. Balendra R, Isaacs AM. C9orf72-mediated ALS and FTD: multiple pathways to disease. Nat Rev Neurol. 2018; 14(9): 544-558, doi: 10.1038/s41582-018-0047-2, indexed in Pubmed: 30120348.

17. Testa $D$, Lovati $R$, Ferrarini $M$, et al. Survival of 793 patients with amyotrophic lateral sclerosis diagnosed over a 28-year period. Amyotrophic Lateral Sclerosis and Other Motor Neuron Disorders. 2009; 5(4): 208-212, doi: 10.1080/14660820410021311.

18. Miller RG, Mitchell JD, Moore DH, et al. Riluzole for amyotrophic lateral sclerosis (ALS)/motor neuron disease (MND). Cochrane Database Syst Rev. 2000; 4(2): CD001447-206, doi: 10.1002/14651858.CD001447, indexed in Pubmed: 10796796.

19. Aboussouan LS, Khan SU, Banerjee M, et al. Objective measures of the efficacy of noninvasive positive-pressure ventilation in amyotrophic lateral sclerosis. Muscle Nerve. 2001; 24(3): 403-409, doi: 10.1002/1097-4598(200103)24:3<403::aid-mus1013>3.0.co;2-3, indexed in Pubmed: 11353427.

20. Kleopa KA, Sherman M, Neal B, et al. Bipap improves survival and rate of pulmonary function decline in patients with ALS. J Neurol Sci. 1999; 164(1): 82-88, doi: 10.1016/s0022510x(99)00045-3, indexed in Pubmed: 10385053.

21. Davidson AC, Banham S, Elliott M, et al. BTS Standards of Care Committee Member, British Thoracic Society/Intensive Care Society Acute Hypercapnic Respiratory Failure Guideline Development Group, On behalf of the British Thoracic Society Standards of Care Committee. BTS/ICS guideline for the ventilatory management of acute hypercapnic respiratory failure in adults. Thorax. 2016; 71 Suppl 2: ii1-i35, doi: 10.1136/thoraxjnl-2015-208209, indexed in Pubmed: 26976648.

22. Bourke SC, Tomlinson M, Williams TL, et al. Effects of non-invasive ventilation on survival and quality of life in patients with amyotrophic lateral sclerosis: a randomised controlled trial. Lancet Neurol. 2006; 5(2): 140-147, doi: 10.1016/S1474-4422(05)70326-4, indexed in Pubmed: 16426990. 

Jarosław Woroń ${ }^{3}$, Teresa Weber-Lipiec ${ }^{2}$

${ }^{1}$ Klinika Leczenia Bólu i Opieki Paliatywnej, Katedra Chorób Wewnętrznych i Gerontologii,

\section{Postępowanie w zaostrzeniu}

\section{niewydolności oddechowej u pacjenta z rozpoznaniem stwardnienia zanikowego bocznego}

Artykuł jest tłumaczeniem pracy: Blacharska-Krzanowska K.A., Strzępek K.A., Woroń J., Weber-Lipiec T. How to manage exacerbation of respiratory failure in a patient diagnosed with amyotrophic lateral sclerosis.

Palliat. Med. Pract. 2020 tom 14, nr 1: 44-50.

Należy cytować wersję pierwotną.

Piśmiennictwo znajduje się na stronach 49-50.

\section{Streszczenie}

Stwardnienie zanikowe boczne (ALS, amyotrophic lateral sclerosis) to wyniszczająca choroba neurodegeneracyjna o niejasnej patogenezie, prowadząca do uszkodzenia neuronów ruchowych. Długość życia pacjentów po rozpoznaniu wynosi 2-5 lat. Pomimo licznych badań klinicznych oraz pewnych postępów w zrozumieniu patologii ALS, nie udało się opracować żadnego leczenia skutecznie hamującego postęp choroby. Celem niniejszej pracy było opisanie historii choroby u pacjenta, od rozpoznania poprzez wystąpienie cech niewydolności oddechowej, aż po rozpoczęcie wentylacji nieinwazyjnej (NIV, non-invasive ventilation), wraz z oceną skuteczności leczenia przy zaostrzeniu niewydolności oddechowej. Stwardnienie zanikowe boczne jest chorobą nieuleczalną, ale wiele z jej objawów można złagodzić; w związku z tym leczenie winno być ukierunkowane na poprawę jakości życia oraz utrzymanie niezależności i komfortu pacjenta tak długo, jak to tylko możliwe. Poprawa jakości życia oraz wydłużenie jego długości to obecnie dobrze już znane zalety NIV.

Palliat Med Pract 2020; 14, 1: 51-57

Słowa kluczowe: stwardnienie zanikowe boczne, niewydolność oddechowa, wentylacja nieinwazyjna, przewlekła obturacyjna choroba płuc

\section{Wstęp}

Stwardnienie zanikowe boczne (ALS, amyotrophic lateral sclerosis) to wyniszczająca choroba neurodege- neracyjna o zasadniczo nieznanej etiologii. W większości przypadków ALS występuje w sposób sporadyczny, bez określonych czynników ryzyka; 5-10\% przypadków stanowią postacie uwarunkowane rodzinnie,

\section{Adres do korespondencji:}

Katarzyna Anna Blacharska-Krzanowska

Klinika Leczenia Bólu i Opieki Paliatywnej, Katedra Chorób Wewnętrznych i Gerontologii,

Collegium Medicum, Uniwersytet Jagielloński, Kraków

e-mail: kkrzanowska@op.pl 
dziedziczone głównie w sposób autosomalnie dominujący oraz $w$ mniejszym stopniu autosomalnie recesywny i związany z chromosomem X [1]. W 20-30\% przypadków choroby $w$ formie warunkowanej rodzinnie dziedziczonej w sposób autosomalnie dominujący obserwuje się mutację dysmutazy ponadtlenkowej miedziowo-cynkowej (SOD1). Do niedawna uważano, że połączenie uwarunkowań środowiskowych i genetycznych ma istotny wpływ na ryzyko wystąpienia sporadycznego ALS, jednak obecnie wiadomo, że wspomniana mutacja nie jest jedyną ani najczęściej występującą (20\%), gdyż zidentyfikowano inne mutacje, na przykład w genach C9ORF72 (34\%), TARDBP (6,5\%), FUS (3-5\%), jak również mutacje sporadyczne. Inne badania wskazały na kilka czynników wpływających na czas trwania choroby oraz wiek wystąpienia pierwszych objawów; w populacji azjatyckiej oraz u osób płci męskiej zaobserwowano wcześniejsze rozpoznanie [2, 3]. Z drugiej strony, późniejsze wystąpienie pierwszych objawów ALS wiąże się z krótszym życiem od rozpoznania [4].

Badania przeprowadzone przez Mitchell i wsp. w grupie 1288 pacjentów poddanych kompleksowej ocenie występowania warunków poprzedzających rozpoznanie ALS wykazały, że takie jednostki chorobowe, jak zapalenie stawów, choroby neurologiczne inne niż ALS, schorzenia wątroby, przewlekła obturacyjna choroba płuc (POChP), schorzenia nerek, astma, cukrzyca, nadciśnienie tętnicze, otyłość oraz hiperlipidemia występowały w grupie pacjentów z ALS statystycznie rzadziej niż w grupie kontrolnej dopasowanej pod względem wieku, płci i miejsca zamieszkania [5]. Autorzy zakrojonego na szerszą skalę badania potwierdzili obecność choroby poprzedzającej ALS, częstsze występowanie schorzenia neuronów ruchowych u pacjentów z chorobami poprzedzającymi oraz ujemną korelację pomiędzy wiekiem rozpoznania a czasem trwania choroby [6]. Powyższe wyniki potwierdziło kilka mniejszych badań, co może stanowić silne poparcie dla ewentualnych hipotez neuroprotekcyjnych $[7,8]$.

Rozpoznanie ALS opiera się na obrazie klinicznym, badaniu neurologicznym, badaniach elektrofizjologicznych oraz diagnostyce różnicowej. W 1994 roku Grupa Badawcza ds. schorzeń neuronów ruchowych Światowej Federacji Neurologii (World Federation of Neurology) opracowała i opublikowała kryteria diagnostyczne, które po zmianie w 1998 roku (El Escorial World Federation of Neurology) i ocenie przez zespół ekspertów w 2006 roku zaowocowały opracowaniem tak zwanego algorytmu Awaji (Konferencja Uzgadniająca Międzynarodowej Federacji Neurofizjologii Klinicznej [IFCN, International Federation of Clinical Neurophysiology]) [9]. Aktualne kryteria rozróżniają trzy postacie kliniczne ALS: ALS klinicznie pewne, ALS klinicznie prawdopodobne oraz ALS klinicznie prawdopodobne - poparte laboratoryjnie. Przyjmuje się, że około $10 \%$ pacjentów z początkowym podejrzeniem ALS w rzeczywistości cierpi na inne schorzenia, w związku z czym schorzenie neuronów ruchowych należy odróżnić od innych chorób o objawach takich samych lub podobnych, jak w przypadku ALS, należą do nich: radikulomielopatia szyjna, miastenia cięż$\mathrm{ka}$, wieloogniskowa neuropatia ruchowa z blokiem przewodzenia (MMN-CB, multifocal motor neuropathy with conduction block), rdzeniowy zanik mięśni (SMA, spinal muscular atrophy), stwardnienie rozsiane (MS, multiple sclerosis) oraz choroba Kennedy'ego (opuszkowo-rdzeniowy zanik mięśni [SBMA, spinal and bulbar muscular atrophy]) [8]. Z tego względu zaleca się przeprowadzenie dalszych badań, takich jak rezonans magnetyczny (MRI, magnetic resonance imaging) mózgu i rdzenia kręgowego, badania płynu mózgowo-rdzeniowego (CSF, cerebrospinal fluid) oraz pewne badania serologiczne. Badania elektrofizjologiczne wykonywane $w$ ramach postępowania diagnostycznego również pomagają wykluczyć inne procesy chorobowe. Cechą kliniczną charakterystyczną dla ALS jest połączenie objawów związanych z uszkodzeniem neuronu ruchowego górnego (UMN, upper motor neuron) oraz neuronu ruchowego dolnego (LMN, lower motor neuron) o przebiegu progresywnym [10]; należy jednak zwrócić uwagę, że natężenie objawów uszkodzenia neuronów ruchowych dolnego i górnego nie musi być identyczne oraz iż nie wszystkie konkretne objawy muszą występować.

Uszkodzenie i stopniowy zanik neuronów ruchowych w rogach przednich rdzenia kręgowego, neuronów ruchowych w korze mózgowej oraz jąder nerwów czaszkowych prowadzi do rozwoju specyficznego obrazu klinicznego. Spastyczność oraz wzmożone lub nieprawidłowe odruchy mięśniowe to objawy uszkodzenia górnego neuronu ruchowego, zaś niedowład wiotki, zanik mięśni szkieletowych, fascykulacja oraz zanik lub brak odruchów mięśniowych wskazują na postępujące uszkodzenie rogów przednich rdzenia kręgowego oraz jąder nerwów czaszkowych.

Początek choroby zwykle sygnalizują objawy w obrębie kończyn górnych - osłabienie mięśni rąk i przedramion, ale może ona także rozpoczynać się w regionie obręczy barkowej lub w kończynach dolnych - zazwyczaj osłabieniem zgięcia grzbietowego (objaw opadającej stopy). Jest to klasyczna postać choroby, odpowiadająca za ponad dwie trzecie przypadków. U niektórych pacjentów początkowym objawem jest niedowład kończyn dolnych.

Opuszkowa postać ALS, na którą cierpi około $20 \%$ wszystkich pacjentów z ALS, cechuje się wystąpieniem zaburzeń mowy i połykania (postępująca 
dyzartria). Uszkodzenie dolnych neuronów ruchowych powoduje stopniowo postępującą duszność, początkowo wysiłkową, a w końcu spoczynkową. Ograniczona sprawność przepony może prowadzić do duszności typu ortopnoe oraz zaburzeń oddychania podczas snu. Zaburzenia oddychania zazwyczaj pojawiają się w późnym stadium choroby, choć istnieją opisane przypadki ALS, w których objawy niewydolności oddechowej pojawiły się we wczesnym stadium choroby [12], często prowadząc do aspiracji, a następnie do zachłystowego zapalenia płuc, które może być bezpośrednią przyczyną śmierci pacjenta.

W kilku badaniach wykazano związek pomiędzy ALS a zaburzeniami poznawczymi i otępieniem czołowo-skroniowym (FTD, fronto-temporal dementia). Otępienie czołowo-skroniowe stwierdzono maksymalnie u $15 \%$ osób z ALS, zaś kolejne 35\% może wykazywać oznaki zaburzeń płatu czołowego, ze zmianami w sferze zachowania i w sferze poznawczej. Istnieje całe spektrum pomiędzy czystym FTD a czystym ALS, z szerokim rozrzutem pomiędzy tymi skrajnościami, szczególnie w przypadku osób z genem C9orf72, a objawy ALS mogą wystąpić po rozpoznaniu FTD [13-16]. Zaburzenia funkcji poznawczych obejmują problemy z funkcjami wykonawczymi, posługiwaniem się językiem, zapamiętywaniem i funkcjami wzrokowo-przestrzennymi. Typowe zmiany w zachowaniu obserwowane w przebiegu choroby obejmują apatię, obojętność, rozhamowanie, nieodpowiednie zachowanie i zaburzenia zwyczajów żywieniowych. Nie obserwuje się zaburzeń czucia powierzchniowego lub głębokiego, choć może wystąpić ból nocyceptywny, wynikający z różnych przyczyn, na przykład ograniczonej ruchomości, skurczy mięśni, spastyczności lub innych schorzeń wspótistniejących, między innymi zaburzeń neuropatycznych w przebiegu cukrzycy.

Stwardnienie zanikowe boczne to choroba nieustannie postępująca o przebiegu niemal zawsze liniowym, która nieuchronnie prowadzi do śmierci; prędkość postępowania wykazuje zmienność międzyosobniczą, bez okresów remisji i zaostrzenia, ale także bez okresów stabilności objawów. Niemal 25\% pacjentów umiera w ciągu 2 lat od rozpoznania, zaś połowa przeżywa 3-4 lata; występują jednakże przypadki, w których długość życia wynosi ponad 10 lat. Długość życia powyżej 10 lat wykazuje około $5 \%$ pacjentów [17]. Średni czas trwania choroby wynosi 4 lata.

Celem niniejszej pracy był opis pacjenta, u którego rozpoznano ALS, ze szczególnym naciskiem na kwestie kliniczne związane $z$ zastosowaniem wentylacji nieinwazyjnej $w$ okresach zaostrzenia niewydolności oddechowej.

\section{Opis przypadku}

Siedemdziesięciosiedmioletni mężczyzna ze schorzeniem neuronów ruchowych (ALS) zgłosił się na oddziału medycyny paliatywnej celem kwalifikacji do wdrożenia wentylacji nieinwazyjnej (NIV, non-invasive ventilation). Szczegółowy wywiad neurologiczny wykazał obniżoną siłę mięśni kończyn dolnych, stopniowo pogarszającą się przez ostatnie 8 lat, wraz z występującym od kilku miesięcy dystalnym osłabieniem kończyn górnych; stan ten wiązał się z niedowładem kończyn dolnych, sennością w ciągu dnia, porannym zmęczeniem i występującą od miesiąca stopniowo pogarszającą się dusznością, odczuwaną szczególnie podczas wysiłku fizycznego, jak również atakami duszności w nocy, pogarszającym się osłabieniem, opisywanym przez pacjenta jako "utrata sił", problemami z wymową słów, brakiem apetytu wraz ze znaczną utratą masy ciała oraz niestrawnością. Ponadto pacjent zgłosił powtarzające się odkładanie śluzowatej wydzieliny w swoich drogach oddechowych, zmuszające go do porannego odkaszlenia, zwiększone wydzielanie śliny, szczególnie w nocy, a także nasilony kaszel bez odkrztuszania, który do tej pory wiązał ze swoją POChP.

Wywiad wykazał, że rosnące osłabienie kończyn dolnych było powodem ciągłych badań diagnostycznych i badań neurologicznych, jak również kilku pobytów w szpitalu; podczas ostatniego pobytu w 2017 roku stwierdzono podejrzenie schorzenia neuronów ruchowych i rozpoznano polineuropatię sensomotoryczną. Z uwagi na wyniki badania elektromiograficznego, wskazujące na obecność zmian neuropatycznych niespełniających neurofizjologicznej części kryteriów El Escorial, pacjenta przekazano do kliniki neurologii, gdzie na podstawie zgłaszanych przez pacjenta postępujących objawów osłabienia mięśniowego i niewydolności oddechowej oraz dodatkowych badań potwierdzono schorzenie neuronów ruchowych. Pacjent miał wiele chorób wspótistniejących, w tym POChP z występującymi od czasu do czasu okresami zaostrzeń, wymagającymi czasowego wzmocnienia leczenia ( $w$ dostarczonych wynikach badań czynnościowych układu oddechowego odnotowano liczne wystąpienia obniżonych wartości $\mathrm{FEV}_{1}$ ), rozstrzenie oskrzeli, chorobę niedokrwienną serca, historię zawałów serca: w 2008 roku leczonego angioplastyką wieńcową obejmującą wszczepienie stentu metalowego (BMS, bare metal stent) do prawej tętnicy wieńcowej (RCA, right coronary artery) oraz w 2012 roku leczonego przezskórną interwencją wieńcową ( $\mathrm{PCl}$, percutaneous coronary intervention) obejmującą wszczepienie BMS do gałęzi okalającej (LCx, left circumflex artery) oraz stentu uwalniającego lek (DES, drug-eluting stent) do gałęzi międzykomo- 
rowej przedniej (LAD, left anterior descending artery), zaburzenia rytmu serca $w$ postaci napadowego migotania przedsionków, przewlekłą niewydolność serca, nadciśnienie tętnicze, zwężenie kanału kręgowego, historię operacji stabilizacji kręgosłupa lędźwiowego w 2013 roku oraz zwyrodnieniowe i związane z dyskopatią zmiany kręgosłupa lędźwiowego. $Z$ uwagi na liczne zaostrzenia postępującej niewydolności oddechowej, pacjent kilkukrotnie poddawany był obserwacji na oddziale pomocy doraźnej i hospitalizacji na oddziałach chorób wewnętrznych i pulmonologii.

W styczniu 2019 roku, z uwagi na chorobę nerwowo-mięśniową współistniejącą z POChP, pacjenta przeniesiono na oddział pulmonologii $w$ celu weryfikacji wskazań do NIV. Gazometria krwi tętniczej wykonana podczas jego pobytu wykazała przejściową hipoksemię, bez hiperkapni i kwasicy; badania czynnościowe układu oddechowego wykazały cechy poważnej, nieodwracalnej obturacji, przy wartości FEV 1 wynoszącej $42 \%$; pletyzmografia nie wykazała cech choroby restrykcyjnej, zaś zdolność dyfuzyjna płuc dla tlenku węgla (DLCO, diffusion lung capacity for carbon monoxide) wyniosła $62 \%$ przewidywanej wartości (wyniki stabilne w porównaniu z poprzednimi). Dodatkowo wykonano polisomnografię, która nie wykazała zaburzeń oddychania $w$ trakcie snu. W trakcie jednego $z$ pobytów pacjenta na oddziale pulmonologii rozwinęła się infekcja dolnych dróg oddechowych; po nieudanych próbach leczenia i wykonaniu posiewu plwociny, w którym wyhodowano bakterie Haemophilus influenzae i Moraxella catarrhalis, rozpoczęto antybiotykoterapię celowaną, co przyniosło poprawę stanu ogólnego pacjenta. Jednocześnie wykonano bronchoskopię z zassaniem wydzieliny z drzewa oskrzelowego; potwierdzono obecność patogenów w materiale biologicznym, a leczenie uzupełniono o rehabilitację oddechową z drenażem ułożeniowym oskrzeli.

Przy przyjęciu pacjent $w$ stanie ogólnym dość dobrym, w logicznym kontakcie słownym, budowa ciała normosteniczna; badanie fizykalne: osłuchiwanie ujawnito ściszenie szmeru pęcherzykowego nad polami płucnymi oraz niewielkie, pojedyncze rzężenia przy podstawach płuc, miarowa akcja serca przy około 90 uderzeniach/minutę, ciastowaty obrzęk kończyny dolnej lewej do jednej drugiej podudzia, brzuch w badaniu dotykiem miękki, bez nieprawidłowej masy, skóra sucha, blada, skóra kończyn dolnych plamista, puls wyczuwalny na tętnicach podkolanowej i udowej, niewyczuwalny na tętnicy grzbietowej stopy, zarysy stawów prawidłowe, osłabienie i obniżone napięcie mięśni kończyn dolnych, ruchomość bierna stawów kończyn prawidłowa, brak ruchomości czynnej w stawach skokowych. Badania neurologiczne wykonane przy przyjęciu wykazały dodatnie objawy deliberacyjne (odruchy dłoniowo-bródkowy i pyszczkowy), pojedyncze fascykulacje w obrębie kończyn, łagodny niedowład dystalny kończyn górnych oraz znaczny niedowład kończyn dolnych, bardziej uwydatniony dystalnie i po stronie lewej, zanik mięśni dotyczący głównie mięśni ręki, prawidłowe odruchy ścięgniste w kończynach górnych, obustronnie dodatni objaw Jacobsona, w kończynach dolnych: słabe odruchy kolanowe, brak odruchów skokowego i podeszwowego, brak zaburzeń czucia powierzchniowego, chód brodzący ze znacznym upośledzeniem stania na palcach i w mniejszym stopniu stania na pięcie; pacjent porusza się o dwóch kulach łokciowych.

W trakcie pobytu stan pacjenta pogarszał się, zaobserwowano problemy z odkrztuszaniem i zmianę charakteru wydzieliny z dróg oddechowych; osłuchiwanie ujawniło cechy zwiększonej obturacji i wydłużenie fazy wydechu; nasycenie bez tlenoterapii wynosito $88 \%$. W badaniu fizykalnym zaobserwowano zaciąganie przestrzeni międzyżebrowych oraz zwiększające się obrzęki kończyn dolnych. Nasilające się cechy niewydolności oddechowej spowodowały podjęcie szybkiej interwencji diagnostycznej. Badania laboratoryjne wykazały podwyższone stężenie białka C-reaktywnego $(120 \mathrm{mg} / \mathrm{l})$, prokalcytoniny $(1,13 \mathrm{ng} / \mathrm{ml})$ oraz leukocytów $(15,11 \times 103 / \mu l)$ i neutrofili $(83,4 \%)$; pozostałe badania: RTG klatki piersiowej wykazało obustronne okołooskrzelowe nacieki zapalne, zaś gazometria wykazała hiperkapnię $\left(\mathrm{pO}_{2} 71,4 \mathrm{~mm} \mathrm{Hg}, \mathrm{pCO}_{2} 49,5 \mathrm{~mm}\right.$ $\mathrm{Hg}$ ); USG jamy brzusznej nie wykazało istotnych nieprawidłowości, za wyjątkiem torbieli prawej nerki. Wyniki badania RTG w połączeniu z cechami i objawami oraz wynikami badań laboratoryjnych stanowiły podstawę rozpoznania niewydolności oddechowej wtórnej do odoskrzelowego zapalenia płuc oraz zaostrzenia przewlekłej obturacyjnej choroby płuc.

Pozostałe wyniki badań laboratoryjnych posłużyły do oceny czynności narządów, takich jak nerki i wątroba, w celu dalszego dostosowania leczenia do sprawności narządów. Z uwagi na brak wyników badań bakteriologicznych, w leczeniu zastosowano antybiotykoterapię empiryczną, czyli cefotaksym i lewofloksacynę $w$ dawce indywidualnie dostosowanej do pacjenta, zgodnie z wytycznymi w zakresie postępowania w przypadku szpitalnego zapalenia płuc, z uwzględnieniem lokalnych fenotypów podatności wyizolowanych drobnoustrojów (Infectious Diseases Society of America and American Thoracic Society 2016), z tą różnicą, że antybiotykoterapię dobrano, opierając się na wynikach badań bakteryjnych wydzieliny z dolnych dróg oddechowych pobranej podczas bronchoskopii wykonanej w styczniu 2019 roku. Zastosowano ponadto terapię kortykosteroidową oraz 
nebulizacje lekiem rozszerzającym oskrzela, steroidem oraz lekiem mukokinetycznym.

Z uwagi na obecność cech niewydolności oddechowej podjęto decyzję o wcześniejszym rozpoczęciu NIV, początkowo po 2 godziny 3 razy dziennie $\mathrm{z}$ zastosowaniem tlenoterapii. Postępowano zgodnie z aktualnymi wytycznymi dotyczącymi rozpoczynania NIV w przebiegu ALS, jak również wytycznymi dotyczącymi postępowania w przypadkach zaostrzeń POChP według GOLD 2019. Z uwagi na malejące stężenie albumin dietę pacjenta uzupełniono o odżywki wysokobiałkowe. Specjalista angiolog ustalił, że niedowład kończyn dolnych był główną przyczyną ich obrzęku i zalecił kompresjoterapię. Kompleksowe podejście do pacjenta, obejmujące farmakoterapię, NIV i leczenie wspomagające (dieta, kompresjoterapia i rehabilitacja oddechowa), pozwoliło na poprawę stanu ogólnego, ustąpienie nacieków zapalnych w RTG oraz rozwiązanie problemów odnotowanych przy osłuchiwaniu. Poprawa została potwierdzona przez kolejne wyniki gazometrii, która została wykonana najpierw pierwszego dnia pobytu, a następnie, po wprowadzeniu kaniuli tętniczej, była wykonywana regularnie od momentu rozpoznania zapalenia płuc z towarzyszącym zaostrzeniem niewydolności oddechowej w celu kontroli równowagi kwasowo-zasadowej oraz wymiany gazowej. Dalsze postępowanie obejmowało kontynuację nebulizacji steroidem, $\beta_{2}$-mimetykiem i bromkiem ipratropiowym, erdosteiną przez pewien czas, metyloprednizolonem z zaleceniem stopniowego zmniejszania dawki, zalecenie kontynuacji podawania kwasu acetylosalicylowego, riluzolu $100 \mathrm{mg}$, ramiprylu, $\beta$-adrenolityku oraz zalecenie kontynuacji terapii przeciwobrzękowej z suplementacją potasu i heparyną drobnocząsteczkową w dawce profilaktycznej. Pacjenta wypisano w optymalnym stanie klinicznym pod opieką rodziny, jak również zespołu wentylacji domowej i kliniki medycyny paliatywnej.

\section{Dyskusja}

Postępujące zaburzenia nerwowo-mięśniowe są najczęstszą przyczyną zgonów w ALS. Zajęcie układu oddechowego to niemal stała cecha ALS, charakteryzująca się zwykle szybkim postępem prowadzącym do niewydolności oddechowej, która może objawiać się w postaci duszności, ale może także przejawiać się poprzez płytki kaszel, zakłócenia snu z częstymi przebudzeniami i/lub nadmierną sennością w ciągu dnia, zmęczenie, poranne bóle głowy, a nawet majaczenie. Fakt ten uzasadnia konieczność przeprowadzania systematycznej, ostrożnej oceny klinicznej w celu wczesnego wykrycia objawów oddechowych związanych z niewydolnością mięśni oddechowych. Nocne zaburzenia oddychania w postaci obturacyjnego bez- dechu sennego lub depresji oddechowej są pośrednio sugerowane przez objawy zgłaszane przez pacjentów, takie jak senność w ciągu dnia, zmęczenie lub poranne bóle głowy. Kontrola stanu pacjenta powinna obejmować badanie fizykalne z oceną postępującego osłabienia mięśni oraz dodatkowe badania w celu oceny postępującego spadku pojemności życiowej płuc (spirometria). Głównym ograniczeniem spirometrii są trudności z wykonaniem tego badania z uwagi na postępującą niewydolność nerwowo-mięśniową w ALS. Podejrzenie obturacyjnego bezdechu sennego należy potwierdzić poprzez tradycyjną polisomnografię.

Pomimo postępu nauk medycznych, postępowanie w przypadku ALS wciąż polega głównie na leczeniu wspomagającym i skupia się na profilaktyce układu oddechowego, w tym poprawie wentylacji i usuwaniu wydzieliny nagromadzonej w drogach oddechowych. W postępowaniu zaleca się podawanie riluzolu, jako że jest to jedyny lek o udowodnionej skuteczności, wydłużający średnią długość życia pacjentów z ALS o 2-3 miesiące. Według badania przeprowadzonego przez Miller i wsp., podawanie riluzolu w dawce $100 \mathrm{mg}$ dziennie zwiększyło odsetek pacjentów przeżywających rok od rozpoznania aż o 15\% i wydłużyło długość życia o niemal 3 miesiące po 18-miesięcznym cyklu leczenia [18], przy braku zaobserwowanego wpływu na subiektywne odczucia pacjentów, szczególnie w zaawansowanym stadium choroby. W dalszych badaniach odnotowano istotne wydłużenie życia pacjentów leczonych z zastosowaniem NIV, średnio o 7-12 miesięcy [19, 20].

Wentylacja nieinwazyjna jest jednym ze sposobów postępowania w przypadku przewlekłej niewydolności oddechowej, zaś w tym wskazaniu zastępuje utraconą czynność układu oddechowego i ma za zadanie poprawić jakość życia w miarę postępu choroby. Aktualne kryteria rozpoczęcia NIV u pacjentów z ALS z ostrą hiperkapniczną niewydolnością oddechową, na przykład wtórną do infekcji dróg oddechowych, obejmują tachypnoe $>20$ oddechów/minutę przy pojemności życiowej < 1 litr lub kwasicę oddechową

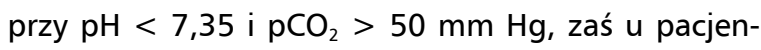
tów ze współistniejącą POChP i ostrą niewydolnością oddechową - obecność kwasicy oddechowej przy $\mathrm{pH}<7,35 \mathrm{i} \mathrm{pCO}_{2}>45 \mathrm{~mm} \mathrm{Hg}$ oraz częstotliwość oddychania $>23 /$ minutę, przy braku odpowiedzi na terapię lekami rozszerzającymi oskrzela [21] (tab. 2).

Obecność chorób współistniejących prowadzących do zaostrzenia niewydolności oddechowej stanowi istotne wyzwanie kliniczne. Czynniki ryzyka POChP są również czynnikami ryzyka częstotliwości i nasilenia zaostrzeń i jako takie stanowią potencjalne cele szybkich interwencji farmakologicznych i wspomagających. Obejmują one rzucenie palenia, zapobieganie infekcjom układu oddechowego oraz unikanie 
Tabela 1. Wyniki badań laboratoryjnych

\begin{tabular}{|c|c|c|c|c|c|c|}
\hline Dzień pobytu & $\mathrm{pH}$ & $\mathrm{pCO}_{2} \mathrm{~mm} \mathrm{Hg}$ & $\mathrm{pO}_{2} \mathrm{~mm} \mathrm{Hg}$ & Nasycenie $\mathrm{O}_{2} \%$ & $\mathrm{HCO}_{3} \mathrm{mmol} / \mathrm{l}$ & BE $\mathrm{mmol} / \mathrm{l}$ \\
\hline Dzień 1 & 7,389 & 37,3 & 93,4 & 94 & 22,7 & $-2,2$ \\
\hline Dzień 14 & 7,274 & 49,5 & 71,4 & 88 & 22,4 & $-1,6$ \\
\hline Dzień 15 & 7,298 & 50,2 & 59,6 & 87 & 23,7 & $-2,5$ \\
\hline $\begin{array}{l}\text { Dzień } 16 \\
\text { godz. } 8.00\end{array}$ & 7,398 & 49,9 & 84,2 & 89 & 24,3 & $-0,8$ \\
\hline $\begin{array}{l}\text { Dzień } 16 \\
\text { godz. } 12.30\end{array}$ & 7,424 & 37,3 & 87,4 & 93 & 24,6 & 0,1 \\
\hline $\begin{array}{l}\text { Dzień } 17 \\
\text { godz. } 8.00\end{array}$ & 7,396 & 42 & 80,3 & 92 & 25 & 0,9 \\
\hline $\begin{array}{l}\text { Dzień } 17 \\
\text { godz. } 12.30\end{array}$ & 7,409 & 89,8 & 39,5 & 93 & 24,8 & 0,4 \\
\hline $\begin{array}{l}\text { Dzień } 18 \\
\text { godz. } 8.00\end{array}$ & 7,18 & 106 & 40 & 96 & 25,6 & 1,3 \\
\hline $\begin{array}{l}\text { Dzień } 18 \\
\text { godz. } 12.30\end{array}$ & 7,422 & 78,4 & 38,9 & 90 & 25,3 & 1,0 \\
\hline
\end{tabular}

Tabela 2. Wskazania do wentylacji nieinwazyjnej u pacjentów z zaostrzeniem przewlekłej obturacyjnej choroby płuc

\section{Wskazania do NIV u pacjentów z zaostrzeniem} POChP

Kwasica oddechowa $\left(\mathrm{PaCO}_{2}>6,0 \mathrm{kPa}\right.$ lub $45 \mathrm{~mm} \mathrm{Hg}$ i pH krwi tętniczej < 7,35)

Silna duszność z objawami wskazującymi na zmęczenie mięśni oddechowych i/lub zwiększony wysiłek oddechowy (używanie pomocniczych mięśni oddechowych, paradoksalne ruchy przepony, zaciąganie przestrzeni międzyżebrowych)

Hipoksemia utrzymująca się pomimo zastosowania tlenoterapii

gwałtownej utraty czynności płuc. Z pogorszeniem objawów i zaostrzeniem reakcji zapalnej związany jest szczególnie spadek wartości $\mathrm{FEV}_{1}$. Tryb oraz intensywność wentylacji mogą znacznie różnić się u poszczególnych pacjentów, w zależności od konkretnych wskazań do NIV. Aktualne kryteria rozpoczęcia terapii z zastosowaniem NIV u pacjentów z ALS są jasne, jednak istnieją przesłanki, które mogą uzasadniać wcześniejsze wdrożenie NIV. W kilku badaniach odkryto dowody na zmniejszenie szybkości utraty czynności płuc [22], choć istnieją także doniesienia wskazujące, że pomimo potwierdzonego spowolnienia utraty czynności płuc, spowolnienie to nie jest jednoznacznie powiązane z momentem rozpoczęcia NIV [19]. Wciąż jednak istnieją korzyści wcześniejszego wdrożenia NIV, które nie są związane ze zmianą szybkości postępu choroby. Wcześniejsze wdrożenie winno być rozważone na przykład u pacjentów niestosujących się do poleceń, szczególnie u tych z objawami opuszkowymi.
Nie zaleca się stałego, długookresowego stosowania NIV z uwagi na ryzyko miejscowego uszkodzenia skóry w miejscu kontaktu z maską, które w skrajnych przypadkach może obejmować nawet owrzodzenie spowodowane uciskiem; szczególnie dotyczy to pacjentów z obniżonym stężeniem albumin spowodowanym wyniszczeniem. Inne ograniczenia tej terapii, wiążące się z wysokim ryzykiem powikłań wentylacji lub niezapewnienia oczekiwanych wyników, obejmują: poważne uszkodzenie opuszkowe, niedrożność dróg oddechowych, znaczne nagromadzenie wydzieliny w drogach oddechowych, niezdolność do utrzymania pozycji odpowiedniej do zastosowania maski lub brak tolerancji na stosowanie maski, niestosowanie się przez pacjenta do poleceń spowodowane na przykład otępieniem lub osłabieniem, upośledzony odruch kaszlowy.

Postępowanie w przypadku nagromadzenia wydzieliny utrudniającej stosowanie NIV stanowi szczególne wyzwanie u chorych z ALS z objawami opuszkowymi, dla których wentylacja inwazyjna (IV, invasive ventilation) z użyciem rurki tracheostomijnej pozostaje metodą preferowaną pod względem skuteczności. Jednakże jako metoda inwazyjna IV powoduje znaczne pogorszenie jakości życia w porównaniu z NIV. Badacze sugerują, że skupienie się na kontroli nagromadzenia wydzieliny w układzie oddechowym jest szczególnie istotne w kontekście przestrzegania zaleceń dla NIV, a wdrożenie odpowiednich technik jej usuwania, z jednoczesną farmakoterapią i rehabilitacją, a następnie zaproponowanie NIV we wczesnym stadium ALS, ma znaczący wpływ na zwiększenie tolerancji na NIV, dając szansę na zastosowanie tej metody u pacjentów z opuszkową postacią ALS. 
Stale rosnący zbiór doniesień naukowych sugeruje, że u chorych z chorobami nerwowo-mięśniowymi, a w szczególności z ALS, którzy w przypadku powikłań w postaci ostrej niewydolności oddechowej otrzymują krótkookresową stałą wentylację inwazyjną, NIV może zmniejszyć potrzebę stosowania wentylacji inwazyjnej, skrócić czas pobytu na OIT i zmniejszyć śmiertelność [19]. U chorych z towarzyszącą niedrożnością dróg oddechowych wymagającą nebulizacji, nebulizację należy stosować $w$ trakcie przerw w NIV. W razie potrzeby pacjentom zależnym od NIV w okresach zaostrzenia leki mogą być podawane za pomocą nebulizatora podłączonego do respiratora. Badania wykazały, że u stabilnych pacjentów leki rozszerzające oskrzela zapewniają większe korzyści, gdy podawane są w trakcie przerw w NIV, co może również ułatwić kaszel i skuteczne wykrztuszanie.

\section{Wnioski}

Poprawa jakości życia oraz wydłużenie jego długości to obecnie dobrze już znane zalety NIV, które występują niezależnie od tego, czy wdrożenie NIV było związane z obowiązującymi kryteriami (hiperkapnia), czy też terapia ta została zastosowana przed wystąpieniem oczekiwanego spadku pojemności życiowej płuc.
Choć optymalny moment wdrożenia terapii NIV jest istotnym czynnikiem, najważniejsza jest pewność, że wszyscy pacjenci kwalifikujący się do wentylacji wspomaganej otrzymają ją, wraz ze wsparciem ze strony doświadczonych zespołów wentylacyjnych. Problemem jest niewątpliwie brak możliwości skorzystania z opieki domowych zespołów hospicyjnych i wspomagających terapię wizyt w klinice medycyny paliatywnej w tym samym okresie, zwłaszcza że zespoły opieki paliatywnej mogą pomóc w podejmowaniu decyzji dotyczących celów i preferencji chorego, jak również mogą zapewnić stałą opiekę ukierunkowaną na łagodzenie objawów. Uwzględnienie kwalifikacji do NIV, jak również potencjalnych korzyści i ryzyka powikłań jest zawsze obowiązkiem lekarza, który powinien poinformować pacjenta o wszelkich ograniczeniach tej metody.

\section{Konflikt interesów}

Autorzy deklarują brak konfliktu interesów.

\section{Finansowanie}

Badanie nie było finansowane.

Artykuł nie zawiera żadnych informacji pozwalających na zidentyfikowanie pacjenta. 